\title{
Mehdi Ghasemi
}

University of Turku, Finland

mehgha@utu.fi

\section{Gender Equality: A Case Study of The Flying Train by Janaki Sooriyarachchi}

Pregledni rad / review paper

Primljeno / received 11. 12. 2013.

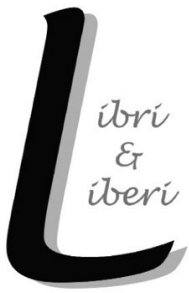

Gender inequality is one of the most important concerns of the world today, even in children's storybooks. The creation of "biased" or "unbiased" storybooks which blur or highlight gender differences help to form gender equality or inequality right from early childhood. Through a thorough examination of The Flying Train (2003), a story written in English for children between six and ten years of age, this paper intends to explain how Janaki Sooriyarachchi - the writer and illustrator of the story - attempts to validate both feminine and masculine voices and visions and balance gender issues both in the text and in the illustrations of the analysed narrative.

Keywords: gender equality, children's storybooks, picturebook, Janaki Sooriyarachchi, The Flying Train

Gender inequality is one of the most important concerns of the world today, manifesting itself even in the texts and illustrations of children's storybooks (JettSimpson and Masland 1993; Ernst 1995; McCabe et al. 2011). As McCabe et al. observe, children's storybooks are a key source in legitimising gender systems and affecting the development of gender identity in children (2011). The main reason is that children are probably more likely to identify with characters that are of the same gender as them, and this may naturally influence their attitudes and shape their perspectives with regard to gender differences right from childhood (Singh 1998; Mendoza and Reese 2001).

Thus, stereotyped portrayals of boys and girls in children's storybooks affect children's interactions with people of the opposite gender. The study by Hamilton et al. (2006) reveals that stereotyped portrayals of genders in children's storybooks 
influence children's attitudes about their future professions, limit their career aspirations and impose limitations on them in their future personal and social lives. Likewise, in their book entitled Still Failing at Fairness, Sadker and Zittleman (2009) enumerate a number of limitations associated with the biased representations of gender identity, amongst them the limitations children find in their choices of clothes, colours, occupations, toys, sports, behaviours and interests that have conventionally been defined for them. They then show how these limitations negatively affect children's personalities. They finally offer some constructive suggestions to counteract the negative effects of such limitations imposed on children, including the use of materials that depict both genders equally in nontraditional roles, activities, and occupations.

Recent studies of children's storybooks have continued to reveal gender stereotypes and inequality in both texts and illustrations of such books (Diekman and Murnen 2004; Anderson and Hamilton, 2005; Hamilton et al. 2006; Fitzpatrick and McPherson 2010; McCabe et al. 2011). For instance, Hamilton et al. examined 200 popular top selling children's picturebooks published from 2001 to 2006 . They found that male characters were present in illustrations and titles $53 \%$ more often than female characters (2006). In their study, McCabe et al. observed that disparity in the representations of genders has diminished over time, but subtle stereotypes and disparities still exist (2011). They found that, for instance, boys appear as central characters in $26.4 \%$ of books, while girls are cast as central characters in $19 \%$ of books.

Writers and illustrators of children's storybooks are more sensitive to issues of gender stereotyping today, and a number of them show a more positive trend in representing gender balance and provide opportunities for children to encounter gender equality. This is a call for the creation of unbiased storybooks and illustrations, which attempt to blur gender inequalities, make children's storybooks more gender-balanced, and help to form gender equality from early childhood. No doubt, parity in the number of male and female characters in the central roles and their proportionate presence in the titles, texts and illustrations of children's storybooks - which are blueprints of social norms and expectations for children - can contribute to the construction of gender equality and identity, simply because this parity and presence imply visibility and importance for both genders. This would help children learn an $\mathrm{ABC}$ of gender equality from early childhood as they learn the $\mathrm{ABC}$ of their own language. $\mathrm{An} \mathrm{ABC}$ of gender equality would include equal value accorded to both men and women as members of society and commitment to the principle that the members of society, regardless of their gender differences, receive equal rights, opportunities and treatment in all spheres of life. 
Seen in this light, an ABC of gender equality in children's storybooks implies that all characters of whatever gender would share an equal voice and vision in the texts and illustrations of stories and would not be treated on the basis of negative stereotypes.

While searching for an appropriate book of this type, I came across Janaki Sooriyarachchi's The Flying Train (2003), which seemed to lend itself for the purpose of this case study. Thus, in this paper, through a thorough examination of The Flying Train, a story written in English for children between six and ten years of age, I explain how Sooriyarachchi - the writer and illustrator of the story - attempts to validate both feminine and masculine voices and visions and balances gender issues in both her texts and illustrations.

Janaki Sooriyarachchi is a highly respected multitalented Sri Lankan author, illustrator, graphic designer and musician. She penned her first story book when she was only eight years old, and her first book was published when she was fourteen years of age. Since then, she has authored and illustrated 206 books for children, including The Flying Train. It merits noting that she has already earned several awards from different foundations for writing and illustrating storybooks for children.

The Flying Train consists of fourteen pages, and the text on each page is accompanied by an illustration, which is both a source of aesthetic delight and of information about the story. The parts of the story told on the first and the last pages of the book are set in this world, while the other twelve pages of the book cover the events that occur in outer space. The book tells the story of Nelly and Timmy, a sister and brother, who are asleep in bed with their two anthropomorphised dolls, along with their own pets, when they are woken by a loud noise - a train flying through their bedroom window and inviting them to hop on board. The train takes all of them on an adventure in space where they find the opportunity to see various things in the sky, including a rainbow, clouds, aliens, stars, the planet Mars, the moon, and even the sun. The train takes them so high that the earth is seen as a small marble. During this adventure, they have the chance to experience and review some of the facts they have learned at school about other planets. On seeing the sun, the children feel that it is dawn, and accordingly they have to get up and go to school. Thus, they ask the flying train to head back, but it refuses and keeps on flying through the sky. They start yelling, but it is to no avail, for the train moves forward. Thus, Nelly proposes to Timmy, the dolls and the pets that they jump off" the train, and all unanimously agree. Timmy counts to three and they all jump off. Their yell makes their mother get up to see what is going on, and they all wake up simultaneously. 


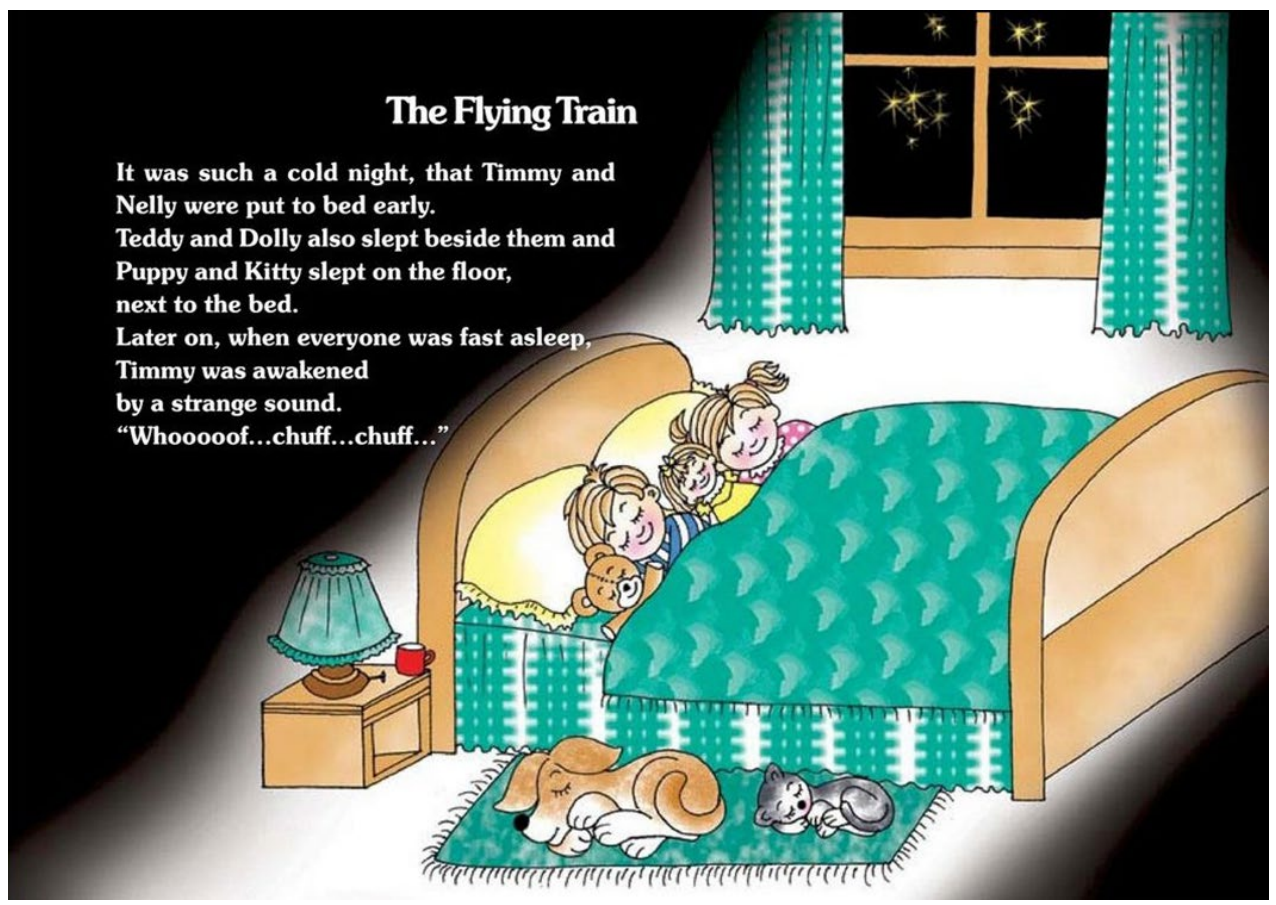

Fig. 1 Nelly and Timmy in their room (Sooriyarachchi 2003: [3]).

Sl. 1. Nelly i Timmy u svojoj sobi (Sooriyarachchi 2003: [3]).

The two main characters of The Flying Train, Nelly and Timmy, are roughly of the same age. In addition, Nelly and her brother are of the same height, which implicitly dismisses "the tall man/shorter woman image" (Paul 1998: 20). They are distinguished pictorially by their hairstyles and the colour of what they wear. Although they both have blond hair, Nelly's hair is longer and is in loose pigtails, while Timmy has shorter hair. Both Nelly and Timmy are wearing pyjamas; however, Nelly has a pyjama top with pink and white dots and pyjama bottoms in pure pink (cf. Sooriayarachchi 2003: 15), whereas Timmy has striped blue and white pyjamas. It is worth noting that although Nelly and Timmy are dressed in typical Western European gender-related colours - pink for Nelly and blue for Timmy - their characterisation is not influenced by that, but is rather established through their actions and initiatives, which will be discussed below in detail. I should add that the book is action-oriented, since it focuses on actions and events rather than on characters and characterisation.

The children sleep in the same bedroom, mostly decorated in green (Fig. 1). Their bedspread, mattress, table lamp, curtains and the mat on which their pets 
sleep are all green, which, according to Perry Nodelman, is the colour of growth, fertility and peace (1988). In The Pleasures of Children's Literature, Nodelman repeats his view about the colour green as follows: "We see pictures in which greens predominate [...] as restful because we associate green with peaceful forests" (1996: 222). He adds that green can signify joy, too (230). In addition to green, the colour brown is observed in their bedroom. Their window and bed frames, in addition to their bedside table and their dog and dolls, are all brown. Sooriyarachchi also uses black which signifies the darkness of night. Perhaps the selection of green and brown and black is an attempt to avoid associations of gender colour stereotypes.

Nelly and Timmy sleep on the same double bed and tightly hold their soft toys. Nelly has a female doll in a yellow dress, called Dolly, and Timmy has a light brown bear, named Teddy. They also have a brown young dog and a grey kitten, called Poppy and Kitty, respectively, which sleep on the floor next to their bed. These six figures are always together from the beginning of the story to the very end and assist one another in all situations. They fall asleep together, dream together, hop on board together, have adventures together, yell in unison, jump off the train together and even wake up together, which signifies that there is a great intimacy between them.

It is worth noting that except for Nelly's pink clothes and Timmy's blue clothes, in the other illustrations of the book Sooriyarachchi avoids using any colour which is associated with gender stereotypes. For instance, when they set off on the space trip, the dominant colour is black, which also signifies mystery. In other illustrations, she uses either brown to show the surface of planets, or navy blue, which, according to Nodelman, suggests serenity, to represent the sky (Nodelman 1966: 222). Sooriyarachchi even attempts to illustrate the moon in a genderless form, as it is shown as a large yellow circle with a smile, with no sign of any particular gender (Fig. 2). According to Nodelman, yellow is the conventional colour of cheerfulness, and, for this reason, it dominates children's books (1988). It should be added that in this book, besides cheerfulness, yellow signifies warmth and energy.

Lissa Paul in her Reading Otherways (1998) considers questions about relationships, offering a methodology which leads to a better understanding of messages conveyed by narratives. One of her question pairs is "who is named? and who is not?" (1998: 16). As mentioned above, all six characters are named in the analysed story. It is worth considering that the dolls and pets have so-called loaded names, which reveal a clear semantic relationship with their respective category and reveal their functions. For instance, the doll is called Dolly, the bear is called Teddy, the kitten's name is Kitty, and the dog Poppy (which is similar to "puppy"). These 


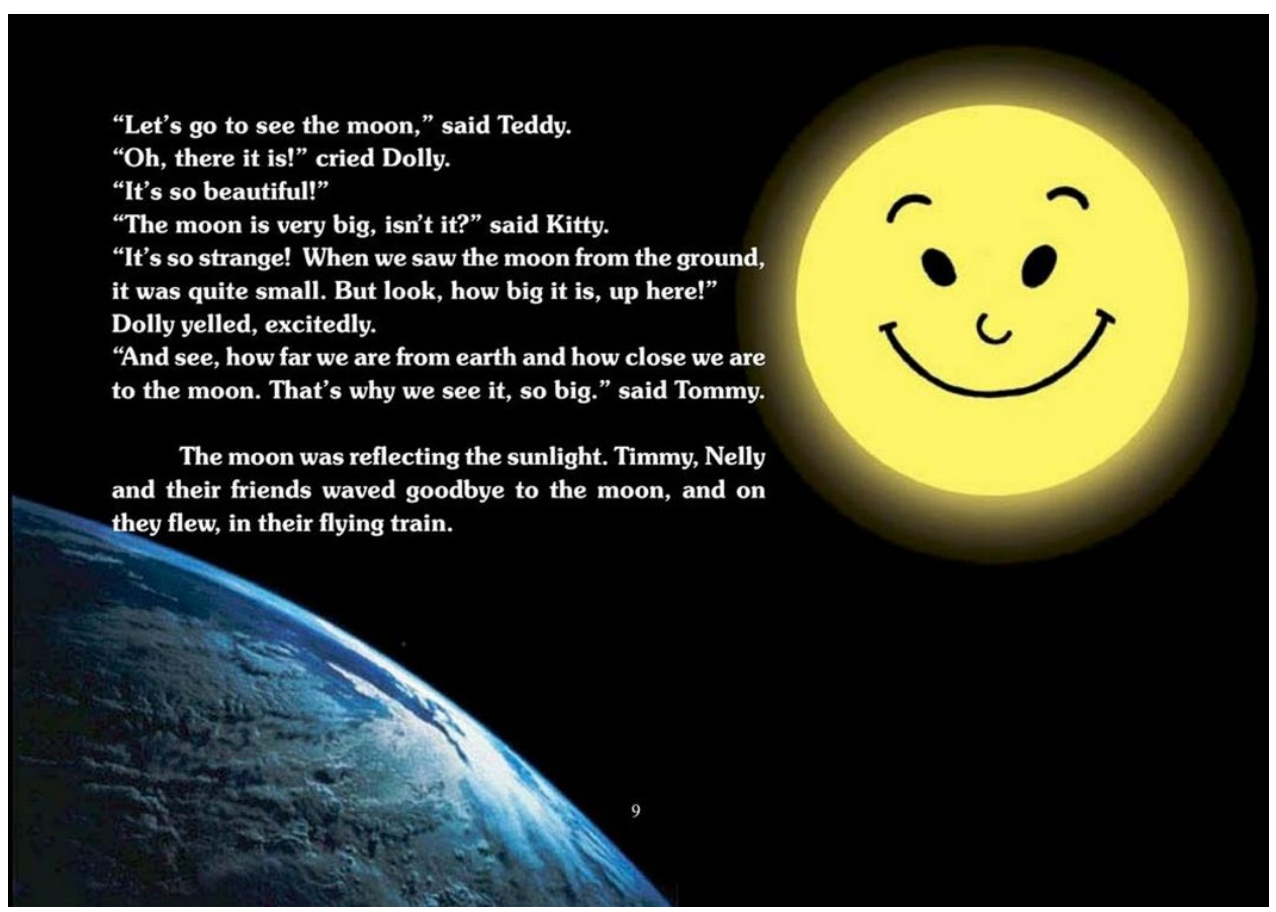

Fig. 2 The smiling genderless moon (Sooriyarachchi 2003: 9).

Sl. 2. Nasmijani mjesec neodređenoga spola (Sooriyarachchi 2003: 9).

names clearly show their bearers' types. However, the other figures, including the flying train and Mother, can also be considered loaded proper names.

The flying train, which takes everyone to the sky and to other planets, is mostly red, which stands for excitement (Fig. 3). It should be noted that Sooriyarachchi has also used green and yellow hues for a few parts of the train; however, red is its predominant colour. The flying train looks very happy, and, in all illustrations, it wears a smile on its face. It has three compartments, each of which contains two passengers. Nelly and Timmy sit in the front compartment, Poppy and Kitty in the second, and Teddy and Dolly in the last one. They all look excited in the illustration, which is reinforced by the text (Sooriyarachchi 2003: 2-3; emphasis added):

They all looked up toward the sound and saw an amazing sight. "It's a flying train!!!" Timmy and Nelly shouted at once. "Come on everyone!" the train shouted. "I will take you for a ride in the sky. All Abooooooard!"

"What?" everyone cried. "A ride in the sky? How wonderful! Let's get in ... let's get in". So Timmy, Nelly, Puppy, Kitty, Teddy and Dolly jumped into the train.

As seen in this extract, Timmy and Nelly even shout "at once," and they, like the flying train, invite all to join them. The use of the words "all" and "everyone," 


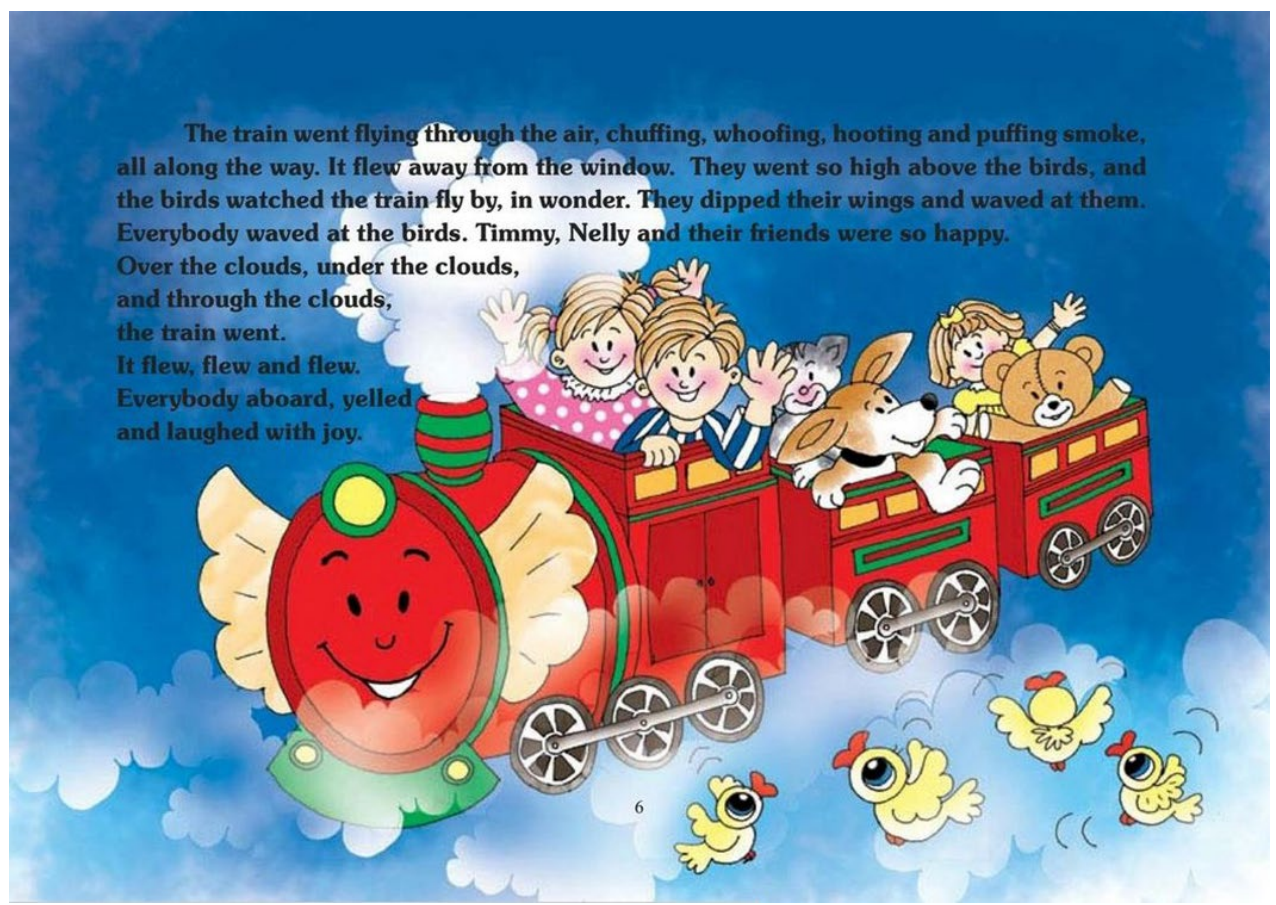

Fig. 3 The flying train and its passengers (Sooriyarachchi 2003: 6).

SI. 3. Leteći vlak s putnicima (Sooriyarachchi 2003: 6).

which are repeated, as well as the utterance of the names of all the characters, signify this quest for equality. In addition, the flying train, which takes all the character for a ride in the sky, does not deprive any of them of this marvellous adventure, including them all. It shouts "All Aboooooord," which signifies a warm invitation and welcome. Even the term "Aboooooord" has got six letter "Os" - one for each character - and it may signify that all characters have their own equal share in this adventure. Another question pair posed by Lissa Paul is relevant for this situation: "who acts? and who is acted upon?" (1998: 16). As discussed, the story revolves around the acts of seven figures. It seems that all these figures act on different occasions in the story. Nelly and Timmy, along with their dolls and pets, jump into the train and have adventure in space. The flying train also acts to invite them all and to take them on this adventure. Up to this point, they act in a parallel way; however, at one point the flying train wants to act upon them when it refuses to return them home. Right at that point, Timmy, Nelly and their companions, who prefer to act and not be acted upon, unanimously decide to jump off the train, and they do so. 
Having Nelly go on an adventure and giving her an active role to handle a tough situation challenges the stereotypical character traits that boy heroes bravely go out into the wider world while girls sweetly undertake domestic activities, stand in the doorways or look out of windows. Moreover, her character traits in this story refuse to represent her as a dependent and submissive character with a secondary role. Thus, to have a male character as the superhero capable of supernatural acts and a helpless dependent female character who cannot survive without the male character's devotion would be to undervalue the capabilities of women and girls. In their analysis of a number of children's storybooks, Fitzpatrick and McPherson observed that female characters are mostly cast as cooks, teachers, nurses and babysitters, while boys are cast as wrestlers, fire fighters, doctors, rescuers and engineers (2009). However, The Flying Train refuses to inscribe the superordinate role for Timmy and the subordinate role for Nelly, and thus it does not revolve around the decisions and acts of Timmy and does not show Nelly as a dependent helpless character. Thus, the equal representation and participation of both male and female characters in the story sends a message to the readers, mostly children, which should be unconsciously taken in and internalised, that the cooperation of both genders results in the creation of a better world.

To achieve this end, Sooriyarachchi portrays her characters according to their competence and efficiency rather than their gender, and both genders appear actively in all conditions, have a voice and vision and present their logic and emotions appropriately, so that gender balance in dialogues, activities, illustrations, etc., is fully observed. Nelly and Timmy both enjoy living in a dreamy genderequal world, where Nelly can experience outdoor adventure and make decisions as fearlessly as Timmy does; this is a dreamy gender-equal world where Timmy can have and can play with a soft toy just as Nelly does, and it is some distance from the traditional perceptions that boys must play with guns and trucks, and girls with dolls. The story depicts a dreamy gender-equal world where Nelly and Timmy both have adventure and acquire scientific knowledge about life on other planets, where no one occupies a less important role than the other, where Nelly and Timmy encourage and assist one another when they are in trouble, and their only difference is limited to their biological features. In this story, both Nelly and Timmy are cast as leaders on different occasions, they are shown in equal and respectful partnership, and act as complements to each other.

It should be noted that imbalance in the number of male and female characters in stories and illustrations generally, as well as in their appearance and participation in the events occurring in the stories, help to make girls invisible and boys hypervisible. In this story, Sooriyarachchi has attempted to keep this balance. As 
we already know, she employs one male character and one female character who appear actively in most illustrations. There are fourteen pictures in this story. Timmy, Nelly, Puppy, Kitty, Teddy and Dolly are always together and appear in ten pictures. The remaining four show the sun, the moon, stars and Mars. It is worth noting that in nine out of ten pictures which show the children and their dolls and pets, the figures in the illustrations are placed almost in the centre of the pages. Naturally, the location of the figures in the pictures signifies their importance. According to Nodelman, "[a] figure at the center of a picture [...] tends to have more weight than those on the sides" (1996: 231). The only picture showing the children and their companions on the side of the page is the one in which the flying train is taking its six passengers toward the glittering stars, which suggests movement from the right to the left.

Another pair of questions comes to mind here: "who speaks? and who is silenced?" (Paul 1998: 16). In this story, Timmy, Nelly, their pets and dolls, in addition to the flying train, speak on different occasions, and none of them is silenced. For instance, Timmy and Nelly utter eight monologues each. In seven cases, they all speak unanimously and the dolls and pets each speak three or four times individually. I would argue that to create equality in the number of male and female characters, in the number of monologues and dialogues each character utters, in the number of illustrations in which the characters appear, as well as in their active roles on all occasions, can be a step toward gender equality. In addition, this voicedness of all the main figures can be interpreted as a plurality of voices and multi-vocation. Seen in this light, every figure in the story has a voice, which is one of the features of identity.

To make a tighter relationship between picture and text, Sooriyarachchi does not place the text on one page or verso and the illustration on the other page or recto. She also refuses to place the text on a white space. Rather, the colours bleed to the edge to cover the whole page, and then she places the text on them. Thus, the pictures are set as the background. This is an attempt to interweave texts and pictures, which integrates picture and text, and, accordingly, the children can view the pictures while they are reading the texts. So, when children open The Flying Train, they encounter both words and pictures simultaneously, and their attention does not move constantly between pictures and words. According to May M. Narahara, "[i]n a picture book, illustrations have an equal responsibility for telling the story" since "pictures serve the purpose in conveying the story" (1998: 7). It should be noted that Sooriyarachchi uses black fonts on light backgrounds and white fonts on dark backgrounds, which are easily seen and read.

As stated above, the characters leave home and have an adventure; however, 
it is not a one-way adventure. Rather, they return home after confronting outer space. Jon Scott and Christine Francis refer to this type of story as a "Home and Not Home" story (1993). The story in The Flying Train starts in the realistic world (Home); it continues into the fantasy world (Not Home) and ends in the realistic world (Home). Seen in this light, this story is circular since the environment that the characters abandon at the outset is the same environment to which they return by the end of the story. Twelve out of the fourteen pages of the book represent outer space (Not Home), and only two pages of the book present the setting in this world (Home). It might seem that by placing the major part of the story within a fantasy setting Sooriyarachchi has the opportunity to create a world of gender equality which can exist only in the imagination. As Maria Nikolajeva aptly states, "[i]t is in fact only fantasy and science fiction that can, with certain reservations, portray female characters free from stereotyping" (150). Thus, the creation of a fantasy world in The Flying Train can be seen as an attempt to leave behind the world of gender inequality, and it can be interpreted as an escape from the world of distances between genders.

I would argue that even the title of the story - The Flying Train, which is not gender-oriented - largely magnifies the idea of a fantasy world. The train which is capable of flying is a means to take the characters, as well as the reader, to a fantasy world. Seen in this light, creating a fantasy world for the book can be seen as escapism; an attempt to create an alternative world so as to escape the unpleasant concerns - gender inequality in the case of this story - of the real world. It can also be stated that Sooriyarachchi uses fantasy elements to provide children with the comparative possibility to compare and contrast the beauty of a gender-equal world with the world wherein they live. The reason for this analysis would be the situation depicted on the last page of the book.

On the last page, as soon as the characters return from their dream-like adventure, they all yell, and it is Nelly's and Timmy's mother who rushes to their bedroom to comfort them. The mother shows up only in the final scene and in the final picture of the book, where she is depicted in a long violet nightgown, wearing short blond hair, and thus our knowledge of the family structure is scarce. However, it can be inferred from this scene that it is either a single-parent family or that the father is asleep. Embracing a positive perspective, we can say that the parents have taken turns to take care of their children, and this night it is the mother's turn to look after her children. However, from an opposite perspective, we can claim that the father refuses to show any interest in or responsibility for child care. It can also be interpreted that upon returning to the world of reality the children face the same gender inequalities running in our world, with the mother showing responsibility 
for child care. It merits noting that in their analysis, Anderson and Hamilton (2005) have scrutinised the representations of fathers and mothers in a number of children's storybooks and observed that mothers in these books were more likely to show responsibility for their children than fathers. They also found that fathers were largely underrepresented and stereotyped as relatively absent or inept partners, and, when represented, they were ineffectual. However, the first page of the story, which occurs in the children's bedroom with no sign or colour of gender inequality or stereotype, can rebut this view that the creation of a fantasy setting is to escape the world of gender inequality. Whatever the reason, the creation of such stories both instruct and amuse children and help them to grow up with this frame of mind.

The Flying Train can be classified as a storybook depicting a world in which gender inequality is to a great extent blurred, suggesting that the creation of a gender-equal world for children is not out of reach - a world in which every citizen of whatever gender has a voice in the texts and a vision in the illustrations. In this story, Janaki Sooriyarachchi implicitly conveys the message that similarity and equality are two different notions, and that we can enjoy equality while having our differences, gender difference in the case of this story. In other words, differences are inevitable, and to achieve equality, these differences need not be assimilated away. Quite the opposite, we can have our differences and enjoy the quality of being equal. Thus, Nelly and Timmy enjoy equality throughout the story while they have different genders.

\section{Conclusion}

The manner in which gender issues are reflected in children's storybooks affects children's perceptions of gender-appropriate attitudes in real life. They learn directly or indirectly from an early age about gender differences through looking at or reading visual stories. How genders are portrayed in children's books thus contributes to the image children develop of their own role and of their gender in society. If societies aim to become more equitable, they need to consider gender equity, and it should start from early childhood. In consequence, children's storybooks should include well-rounded male and female characters, cast in different roles, which can give a gender-equal colour to their world. In this way, the influential role of writers and illustrators in the development of child readers cannot be denied. They can teach children how to colour the world with gender equality and help them to learn an $\mathrm{ABC}$ of gender equality and set it as a goal, just as they acquire the $\mathrm{ABC}$ of their own languages from childhood. In The Flying Train, Sooriyarachchi has to a great extent managed to create a gender-equal atmosphere by taking a distance from the 
stereotyped portrayal of her characters. The picturebook depicts a world wherein all citizens, regardless of their gender differences, have a voice in the texts and a vision in the illustrations. Admittedly, narratives of this type can teach children the basics of gender equality and can shape their attitudes toward gender equality from early childhood. ${ }^{* * *}$

\section{References}

\section{Primary Sources}

Sooriyarachchi, Janaki. 2003. The Flying Train. Sri Lanka: Pannipitiya: Tikiri Publishers. Available at $<\mathrm{http}: / /$ www.childrenslibrary.org/icdl/BookPreview?bookid=sootrai_008 $40003 \&$ route=all\&lang=English\&msg=\&ilang=English $>$.

\section{Secondary Sources}

Anderson, David A. \& Mykol Hamilton. 2005. "Gender Role Stereotyping of Parents in Children's Picture Books: The Invisible Father." Sex Roles 52 (3/4): 145-151.

Diekman, Amanda B., \& Sarah K. Murnen. 2004. "Learning to be Little Women and Little Men: The Inequitable Gender Equality of Nonsexist Children's Literature.” Sex Roles $50(5 / 6): 373-385$.

Ernst, Shirley B. 1995. "Gender Issues in Books for Children and Young Adults." In Battling Dragons: Issues and Controversy in Children's Literature, edited by S. Lehr, 66-78. Portsmouth, NH: Heinemann.

Fitzpatrick, Maureen, \& Barbara J. McPherson. 2010. "Coloring Within the Lines: Gender Stereotypes in Contemporary Coloring Books." Sex Roles 62 (1/2): 127-137.

Hamilton, Mykol, David Anderson, Michelle Broaddus \& Kate Young. 2006. "Gender Stereotyping and Under-representation of Female Characters in 200 Popular Children's Picture Books: A Twenty-first Century Update.” Sex Roles 55 (11/12): 757-765.

Jett-Simpson, Mary \& Susan Masland. 1993. "Girls are not Dodo Birds! Exploring Gender Equity Issues in the Language Arts Classrooms." Language Arts 70 (2): 104-108.

McCabe, Janice, Emily Fairchild, Liz Grauerholz, Bernice A. Pescosolido \& Daniel Tope. 2011. "Gender in Twentieth-Century Children's Books: Patterns of Disparity in Titles and Central Characters." Gender \& Society 25 (2): 197-226.

Mendoza, Jean \& Debbie Reese. 2001. "Examining Multicultural Picture Books for the Early Childhood Classroom: Possibilities and Pitfalls." Early Childhood Research \& Practice 3 (2): 1-38.

Narahara, M. May. 1998. "Gender Stereotypes in Children's Picture Books.” (Exit Project EDEL 570). Long Beach: University of California, Long Beach. (ERIC Document Reproduction Service No. ED419248).

\footnotetext{
* The author wishes to thank Professor Casie Hermansson from the Department of English, Pittsburg State University, Kansas, for her insightful critical reading of an earlier version of this paper.

${ }^{* *}$ We are grateful to Tikiri Publishers (PVT) Ltd. for giving Mr. Mehdi Ghasemi permission to include images of pages from their 2003 edition of the picturebook Thy Flying Train by Janaki Sooriyarachchi in his paper to be published in both printed and electronic versions of this issue of Libri \& Liberi.
} 
Nikolajeva, Maria. 2005. Aesthetic Approaches to Children's Literature: An Introduction. Lanham: The Scarecrow Press, Inc.

Nodelman, Perry. 1988. Words About Pictures: The Narrative Art of Children's Picture Books. Athens, GA: University of Georgia Press.

Nodelman, Perry. 1996. The Pleasure of Children's Literature. New York: Longman Publishers.

Paul, Lissa. 1998. Reading Otherways. Woodchester: The Thimble Press.

Sadker, David \& Karen R. Zittleman. 2009. Still Failing at Fairness: How Gender Bias Cheats Girls and Boys in School and What We Can Do about It. New York: Scribner.

Scott, Jon C. \& Christine D. Francis. 1993. "Home and Not Home in Children's Stories: Getting There - and Being Worth It." Children's Literature in Education 24 (3): 223-233.

Singh, Manjari. 1998. "Gender Issues in Children's Literature.” ERIC Digest. $<$ http://www. ericdigests.org/1999-3/gender.htm>

\section{Mehdi Ghasemi}

Sveučilište Turku, Finska

Turku Universität, Finnland

\section{Ravnopravnost spolova: studija slikovnice The Flying Train autorice Janaki Sooriyarachchi}

Ravnopravnost spolova jedno je od najvažnijih pitanja suvremenoga svijeta, čak i u dječjim knjigama. Stvaranje pristranih ili nepristranih dječjih knjiga koje zamagljuju odnosno osvjetljuju razlike između spolova uspostavlja ravnopravnost ili neravnopravnost spolova već od ranoga djetinjstva. Cilj je ovoga rada detaljnim proučavanjem slikovnice The Flying Train [Leteći vlak] (2003), napisane na engleskome jeziku za djecu od šest do deset godina, objasniti kako autorica Janaki Sooriyarachchi i u tekstu i u ilustracijama analizirane pripovijedi pokušava afirmirati ženske i muške glasove i poglede te problematiku spolova prikazati na uravnotežen način.

Ključne riječi: ravnopravnost spolova, dječje knjige, slikovnica, Janaki Sooriyarachchi, The Flying Train

\section{Gleichstellung der Geschlechter: Studie zum Bilderbuch The Flying Train von Janaki Sooriyarachchi}

Die Gleichstellung der Geschlechter als grundlegende Frage der Gegenwart findet ebenso im Bereich der Kinderliteratur Niederschlag. Das Verfassen von voreingenommen oder unvoreingenommenen Kinderbüchern, in denen Geschlechtsunterschiede verdunkelt oder erhellt werden, trägt seit der frühesten Kindheit zur Herstellung der Gleichheit bzw. Ungleichheit zwischen den Geschlechtern bei. Anhand einer Detailanalyse des englischsprachigen Bilderbuchs The Flying Train [Der fliegende Zug] (2003) für Sechsbis Zehnjährige wird demonstriert, wie die Autorin und Illustratorin Janaki Sooriyarachchi 
im Text und in den Illustrationen sowohl weibliche als auch männliche Stimmen und Sichtweisen berücksichtigt und die Geschlechtsproblematik auszugleichen versucht.

Schlüsselwörter: Gleichstellung der Geschlechter, Kinderbücher, Bilderbuch, Janaki Sooriyarachchi, The Flying Train 